\title{
Testing concrete made with cork powder and steel fibres
}

\author{
Manuel Ignacio Guerra ${ }^{1}$, Andrés Juan ${ }^{1 *}$, Julia Mª Morán ${ }^{1}$, Julia García ${ }^{1}$ and Desirée \\ Rodríguez ${ }^{1}$
}

${ }^{1}$ University of León, Escuela Superior y Técnica de Ingeniería Agraria, Spain.

Accepted 26 October, 2012

\begin{abstract}
Nowadays, greater respect for the environment is a widespread social demand. Since the cork industry generates vast amounts of waste of approximately 20 to $30 \%$, the harvested cork ends up as cork dust with no industrial use. It is becoming necessary to find a way to reuse or recycle this kind of residue. This paper evaluates the mechanical behavior of several samples of concrete containing cork powder $(8 \%)$ and different steel fibres proportions $\left(20\right.$ to $\left.40 \mathrm{~kg} / \mathrm{m}^{3}\right)$. The results indicated that, in spite of the positive effect of the fibres, the cork powder concrete reinforced with steel fibers did not possess enough compressive strength for structural purposes. However, other properties of the result material, like energy absorption and impact behavior seem interesting in terms of certain non-structural applications such as livestock pavements and a surface finish that is less damaging to farm animals.
\end{abstract}

Key words: Concrete, cork powder, steel fibre.

\section{INTRODUCTION}

Nowadays, due to environmental impact caused by construction and industrial activity, the reuse and recycling of agricultural and industrial residues is offered as one of the best alternatives for reducing environmental pollution. The accumulation of some waste products has motivated the search for new applications of these residues in the field of construction. Thus, it can be cited as various original investigations that aim to find a means of recycling concrete from demolitions which act as substitute for aggregates in mixing new concrete (di Maio and Traversa, 2003) or the use of sewage sludge from purification plants in the production of prefabricated concrete paving slabs (Yagüe et al., 2003). In this way, Juan et al. (2010) and Guerra et al. (2009) reported about their works of eco-efficient concretes carried out reusing many kinds of waste products. In the industry of cork in Extremadura, Spain, cork powder is a waste material and a problem for the industry, which does not know what to

${ }^{\star}$ Corresponding author. E-mail: andres.juan@unileon.es. Tel: +34987-291000 ext: 5139. Fax: +34987-291000. do with it except to burn it or send it to landfill (McllveenWright et al., 2000). An estimated 20 to $30 \%$ of the raw cork received at the processing unit is rejected, mainly as cork dust, which has low granulometry and of no interest to the industry (Carvalho, 1996).

Cork is a vegetable material made of grouped dead cells $\left(40\right.$ million $\left./ \mathrm{cm}^{3}\right)$, with a unique form, structure and behaviour, giving some characteristics which are of great interest in the production of certain construction materials. Particularly notable is its exceptional elasticity, its ability to provide thermal and acoustic insulation, its durability and lastly, the fact that it is a natural product, from the cork oak (Quercus suber L.), makes it a renewable resource and a sustainable building material option. It is a material with a very low density, between 0.10 and $0.20 \mathrm{~kg} / \mathrm{dm}^{3}$. It might support considerable pressure, over $90 \mathrm{MPa}$, and has a property of recovering its original sizes when the pressure disappears. These characteristics make cork a product suitable for use in a wide spectrum of applications (Karade et al., 2001). But it also possesses other important characteristics. It is odorless, and it can be considered imputrescible and unalterable, thus retaining its efficiency for a very long 
time (Branco et al., 2007).

A review of the scientific literature suggests that a quite important deal of research has been done on the use of cork in building materials, although the use of natural cellular materials in industrial applications is still uncommon and deserves to be further investigated.

Researchers have investigated the use of cork in composites such as plaster/ cork developed by Hernández-Olivares et al. (1999); cork/beverage carton wastes composite, hydroxypropylcellulose/cork composites and cork/charcoal board composite (Gil, 2009).

The initial motivation for including cork in concrete was to develop lightweight concrete (Aziz et al., 1979). Soon thereafter, cork was added to concrete in order to obtain or modify certain properties such as changes in the density of the final concrete, increasing its lightness (Irle et al., 2004; Novoa et al., 2004; Gonzalez et al., 2007) or adding insulation capacity (Pereira et al., 2004).

Aziz et al. (1979) developed a mix of concrete incorporating cork and concluded that the values obtained for tensile and compressive strength are high when compared with lightweight concrete produced with other organic aggregates. Zbigniew et al. (2005) tested lightweight concrete samples with various percentages of cork but maintained a constant water/cement ratio. They analyzed their properties such as the specific weight and water absorption capability, and determined the grain size dispersion curves. Karade et al. (2006) concluded that cork granules and cement are compatible; that this compatibility decreases as the proportion of cork increases and that coarser grain sizes are more compatible with cement. Branco et al. (2007) analyzed the influence of the incorporation of cork granules, both natural and expanded, in the compressive strength of the material. The results confirmed that the concrete loses strength with the increase of the volume fraction of incorporated cork and that the use of expanded cork leads to the most significant losses. González et al. (2007) evaluated the properties of concrete made with small additions of cork powder produced by the timber industry.

Recently, some papers studied the behavior of cork when subjected to impact and the use of this material in energy absorption systems. Experimental and numerical studies on the dynamic behavior of different types of cork (Gameiro and Cirne, 2007; Gameiro et al., 2007 and 2011) when requested in compression at different strain rates showed that the confinement of cork leads to a significant increase in energy absorption capacity of the structure. Silva (2008) studied the improvement of the seismic response of structural walls using a composite matrix of mortar and dispersed cork elements. Paulino and Teixeira-Dias (2011) explored the ability of cork to act as a material for absorbing impact energy within automotive passive safety and crashworthiness applications.
The above referenced works evidenced the versatility and countless possible applications for cork when used as construction material. In the field of agricultural engineering, farm building floors have been designed using mass concrete for some time now, despite the problems that this represents for certain livestock. The work carried out by de Belie and Rombaut (2003) in this field gives away that the floor's surface finish greatly affects the pressure produced between floor and hoof, and that the use of a softer yet rougher material than concrete would alleviate the damage caused to cows' hooves. So considering the documented cork properties in terms of energy absorption and impact behavior, this paper aims to evaluate the mechanical properties of concrete incorporating cork powder as a feasible alternative for certain kinds of structures used in livestock raising as a material with a finish surface less damaging to animals.

Following Sousa's recommendation (Sousa et al., 2003) on the advisability of undertaking appropriate studies of concrete incorporating additives made from recycled materials, this article discusses the results obtained from tests of different concrete mixes made with a variable addition of cork powder and steel fibres, in order to characterize this type of material.

\section{MATERIALS AND METHODS}

The different concrete mixes were made with Portland cement CEM I $52.5 \mathrm{R}$ and siliceous aggregates with a maximum size of $20 \mathrm{~mm}$. Table 1 and Figures 1 and 2 show the granulometic values and curves of sand and gravel. Specific gravity and humidity were $2.52 \cdot 10^{-3} \mathrm{~kg} / \mathrm{m}^{3}, 2.56 \cdot 10^{-3} \mathrm{~kg} / \mathrm{m}^{3}$ and $1.12 \%, 0.12 \%$ for the sand and the gravel respectively, according to the standard EN 1097-6.

Following the standards EN 1097-2 and UNE 83115-89, the gravel presented a Los Angeles test coefficient of 42, and the sand had a friability coefficient of 11 ; both values are within the recommendation of the Spanish Standard for Structural Concrete (EHE-08).

The added cork came from the powdered waste generated in the cork industry and presented the grain size distribution shown in Table 1 and Figure 3.

Following the recommendations of the manufacturer's company and due to the on site addition of the fibres, their slenderness is limited to 50. Therefore, the selected wavy fibers had the following dimensions: diameter of $1 \mathrm{~mm}, 45 \mathrm{~mm}$ long, wavelength of $8 \mathrm{~mm}$ and amplitude of wave of $0.65 \mathrm{~mm}$ (Figure 4). The fibers used were made from low-carbon steel wire and presented a high yield strength, which varies between 800-1500 MPa.

Several kinds of concretes containing cork powder and different steel fibres proportions were evaluated. Cork and steel fibres are not a substitute for the natural aggregates, but an additional component which is incorporated to the reference or control concrete (CC). Following the recommendations of previous work (González et al., 2007), an eight per cent addition of cork powder was established. Furthermore, in order to obtain better resistant properties of the final product, different quantities of steel fibres $(20$, 30 and $40 \mathrm{~kg}$ of steel fibres per $\mathrm{m}^{3}$ of concrete) were added.

The design of the control concrete mix was calculated using the method of De la Peña (Arredondo, 1968) and the recommendations made by Jiménez Montoya et al. (2010). Due to its non structural use, a concrete with a characteristic resistance of $20 \mathrm{~N} / \mathrm{mm}^{2}$ and a 
Table 1. Aggregates grading results.

\begin{tabular}{cccc}
\hline Mesh size $(\mathbf{m m})$ & Sand & Gravel & Powder cork \\
\hline 0.04 & - & - & 27.90 \\
0.063 & 0.28 & 0.16 & 56.20 \\
0.08 & - & - & 70.70 \\
0.125 & - & - & 85.60 \\
0.16 & 25.05 & 0.28 & - \\
0.32 & 44.80 & 0.33 & 99.90 \\
0.63 & 59.27 & 0.36 & 100.00 \\
1.25 & 73.16 & 0.37 & 100.00 \\
2.5 & 95.31 & 0.38 & 100.00 \\
5 & 100.00 & 1.39 & 100.00 \\
10 & 100.00 & 35.73 & 100.00 \\
20 & 100.00 & 99.37 & 100.00 \\
\hline
\end{tabular}

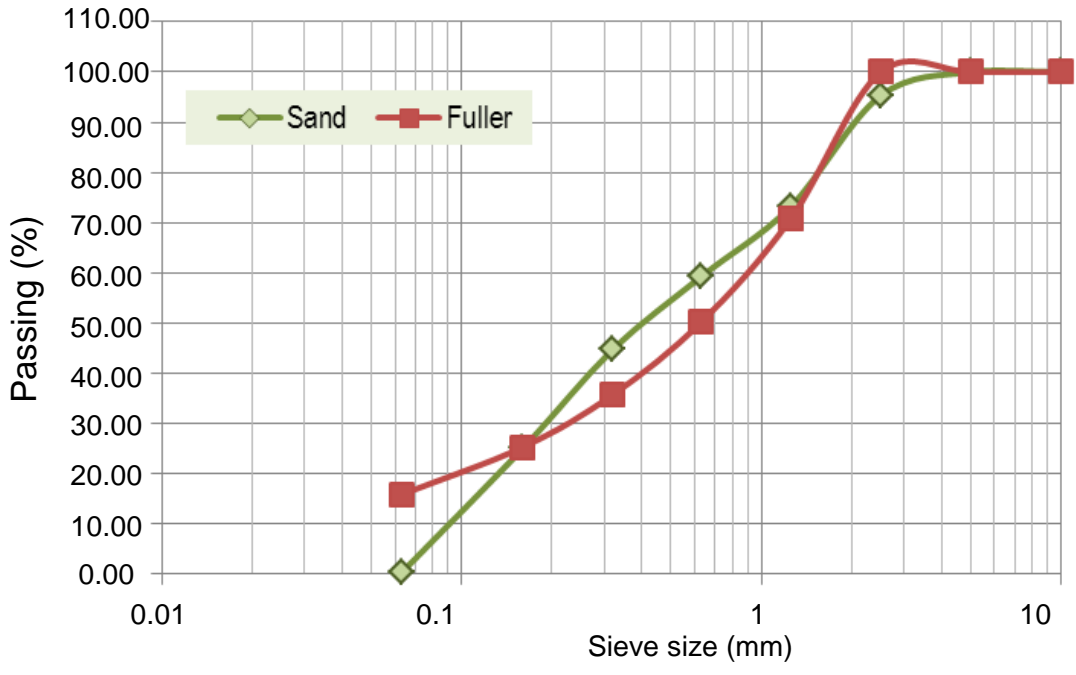

Figure 1. Sand grading curve.

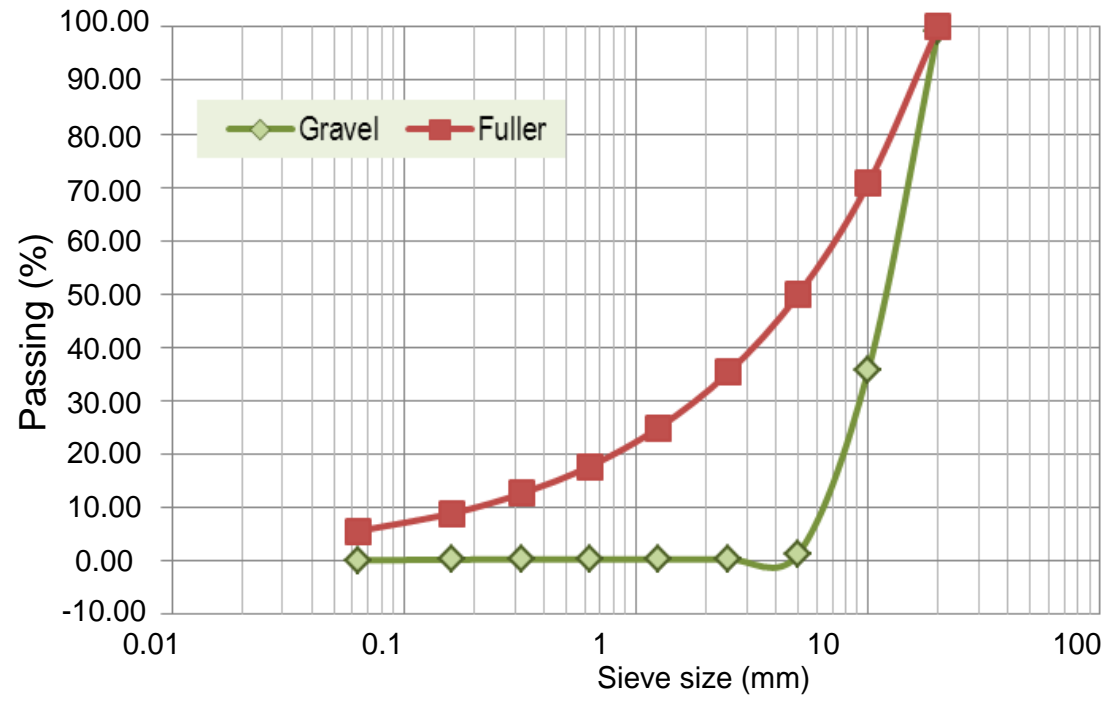

Figure 2. Gravel grading curve. 


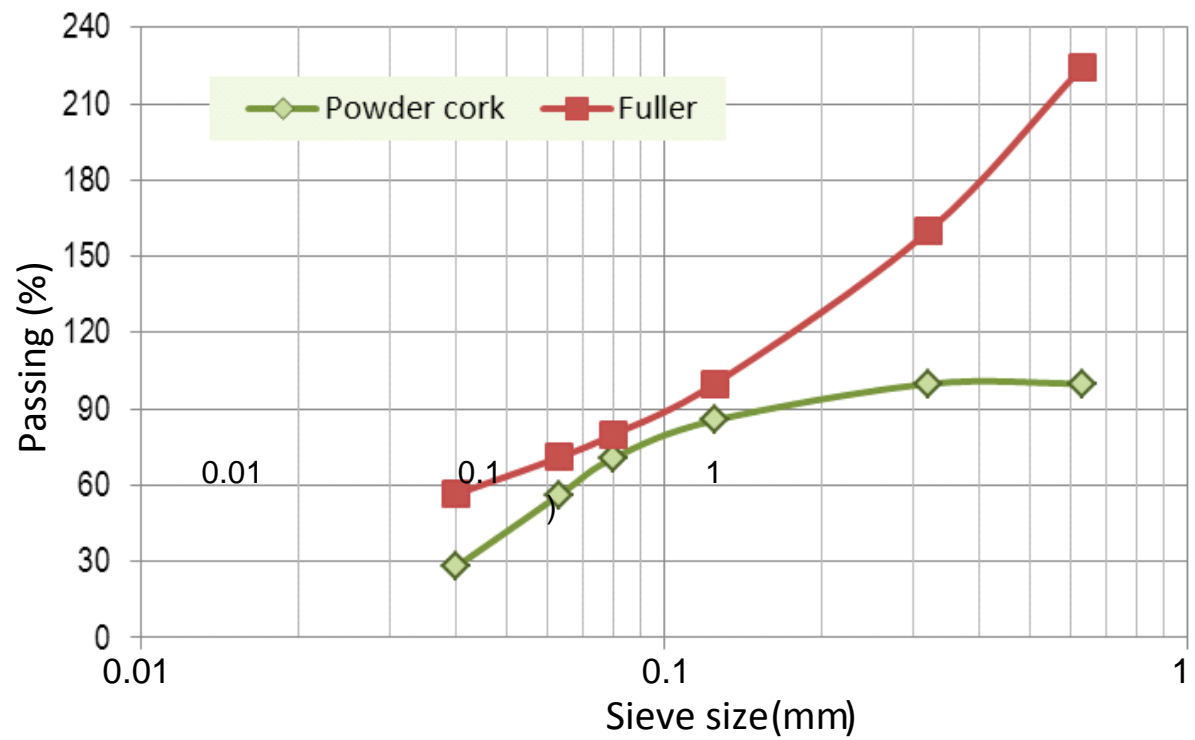

Figure 3. Powder cork grading curve.

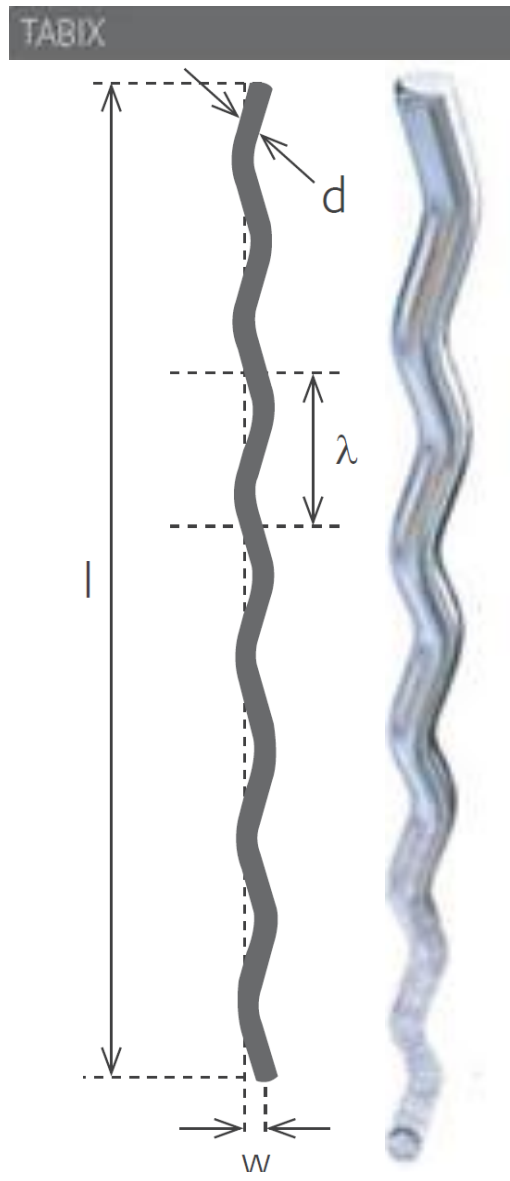

Figure 4. Wave steel fibre "Tabix".

water/cement ratio of 0.64 was proposed. In order to avoid problems in the mixing of the cork with the concrete due to the great capacity of cork powder to absorb water, the theoretical dosage of water was increased (González et al., 2007) in all specimens made with cork up to $590 \mathrm{l} / \mathrm{m}^{3}$ instead of the $190 \mathrm{l} / \mathrm{m}^{3}$ required. The extra water enabled the cork powder concrete production as it would have been impossible to mix otherwise and did not increase the water/cement ratio of the concrete since it is immobilized within the cork. Although a pretreatment of the dust cork could have been taken, the method aforementioned was preferred, due to its simplicity and the possibility of its contrast with that of González et al. (2007). Table 2 summarizes the final components of each type of concrete tested.

The concrete was carried out using a 250 I capacity mechanical concrete mixer and following the next steps:

1) Mixing of part of the fine and coarse aggregate with cork powder, for $10 \mathrm{~min}$.

2) Wetting of the walls, blades and bottom of the concrete mixer.

3) Adding of half the water, the fibres and the cement in the mixer and mixing for about five minutes until an even consistency was reached.

4) Slowly adding of the aggregate/cork mixture and the remaining water and mixing for about ten minutes approximately.

After that, a sample was taken to measure consistency using Abrams's cone, according to EN 12350-2.

The freshly-mixed concrete was used to fill 8 cylindrical specimens $(150 \times 300 \mathrm{~mm})$ and 6 prismatic specimens $(100 \times 100 \times 400 \mathrm{~mm})$ of each type of concrete following the standards EN 12390-1 and EN 12390-2.

Cork powdered concrete presents a very slow curing time due to the high amount of water present in the mix. So, if the curing of the specimens takes place naturally, as in this case, it is necessary to wait at least for 42 days before carrying out any test. However, this paper tested on both ages, 28 days -as established by EHE (Spanish standard for structural concrete)- and 42 days.

Cylindrical specimens were used to carry out compression tests following EN 12390-3 and indirect traction tests (also known as the Brazilian test) and EN 12390-6.

In order to have a complete knowledge of the mechanical behavior of this type of concrete, prismatic specimens were used to carry out tensile strength test following EN 12390-5 (Figure 5 shows the device used and Figure 6 displays the specimens after the test). 
Table 2. Concrete final components $\left(\mathrm{kg} / \mathrm{m}^{3}\right)$.

\begin{tabular}{lcccc}
\hline Components & CC & C20 & C30 & C40 \\
\hline Sand & 770 & 770 & 770 & 770 \\
Gravel & 1123 & 1123 & 1123 & 1123 \\
Cement & 297 & 297 & 297 & 297 \\
Total water & 190 & 590 & 590 & 590 \\
Required water & 190 & 190 & 190 & 190 \\
Extra water & - & 400 & 400 & 400 \\
Powder cork & - & 150 & 150 & 150 \\
Steel fiber & - & 20 & 30 & 40 \\
Abrams cone $(\mathrm{cm})$ & Plastic & Dry & Dry & Dry \\
\hline
\end{tabular}

CC: Control concrete. C20/30/40: Concrete with $20 / 30 / 40 \mathrm{~kg} / \mathrm{m}^{3}$ of steel fibers.

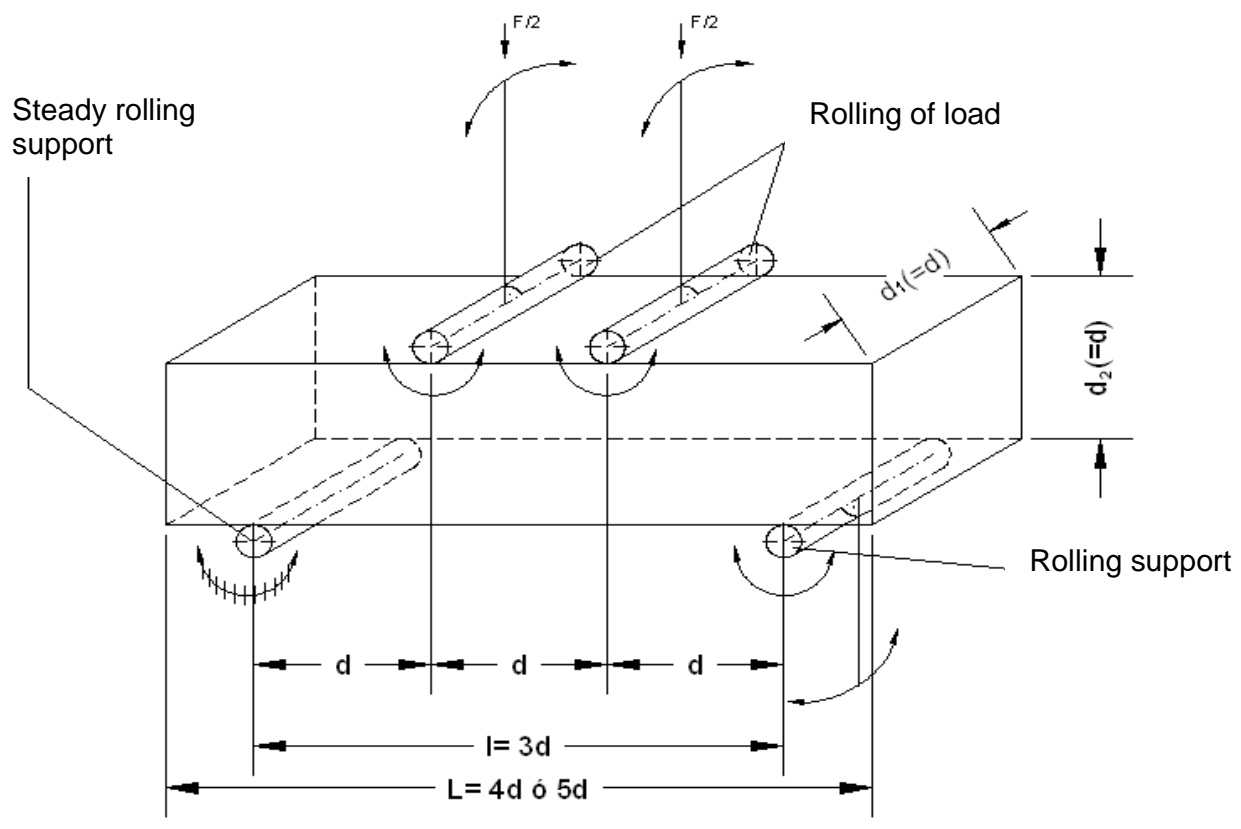

Figure 5. Sketch of the tensile strength device.

\section{RESULTS AND DISCUSSION}

Table 2 shows the slump test results measured trough the Abram's cone. The great cork's water absorption led all samples -except control concrete- to display a dry consistency, which could hinder the concrete workability.

The characteristic compression resistance $\left(f_{c k}\right)$ was worked out from the mean resistance $\left(f_{c m}\right)$ obtained from the 28 and 42 days old specimens tests based on Equation 1:

$f_{c k}=f_{c m}(1-1,64 \delta)$

where $\delta$ represents the variation coefficient of the samples.

The results obtained in the compressive strength tests are given in Figure 7. As previously seen, the older specimens -42 days- achieve better results, although the ultimate strength of the resultant concrete is very low (12 to 20 times lower than control concrete), as the best results of compressive strength were obtained in samples made with addition of $8 \%$ cork powder, $40 \mathrm{~kg} / \mathrm{m}^{3}$ of steel fibers: $f_{c k}=2.6 \mathrm{MPa}$. The data show that steel fibres have significantly improved the ultimate strength, and that the more fibres were added the better results were achieved; up to $85 \%$ of improvement respects the cork powder concrete without reinforcement. Nevertheless, these results rule out any possibility of using this type of concrete as a structural material, although that was not the objective in the first place.

The tensile splitting test was worked out from the break load $(P)$ following Equation 2: 


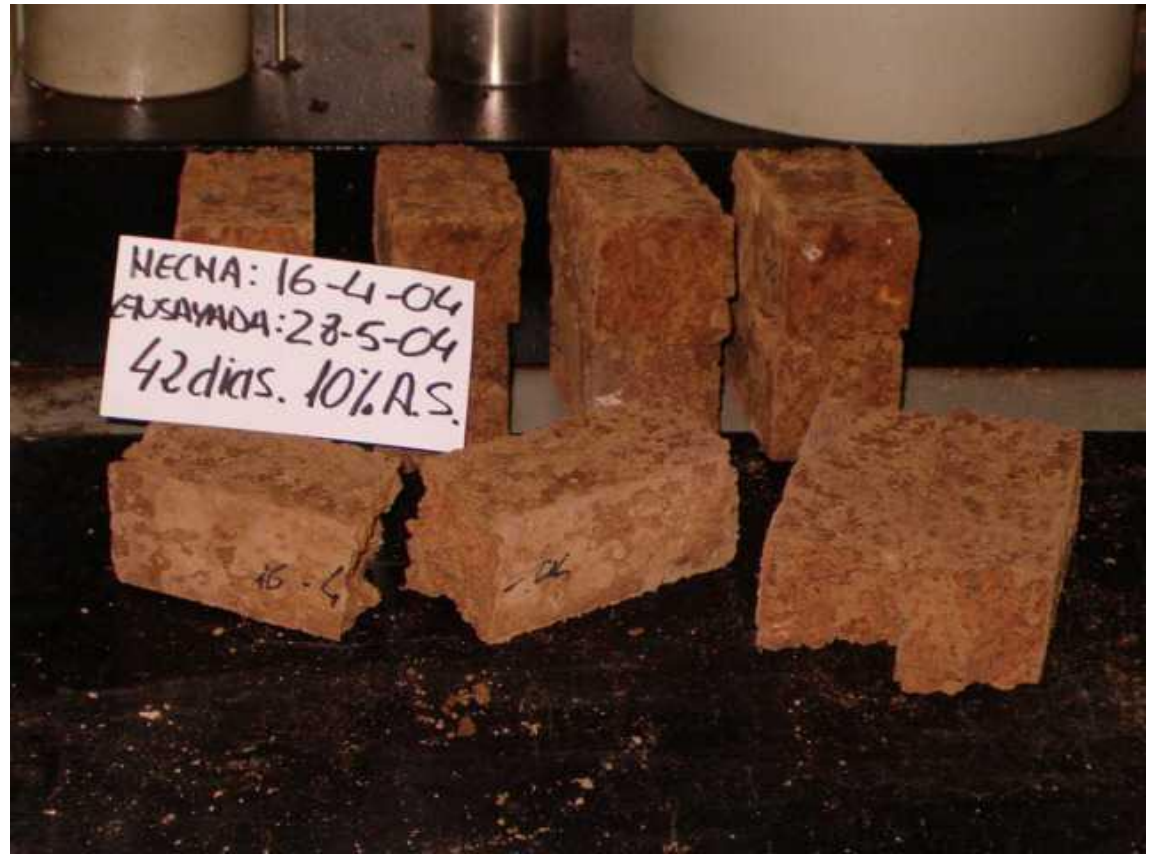

Figure 6. Tensile strength test.

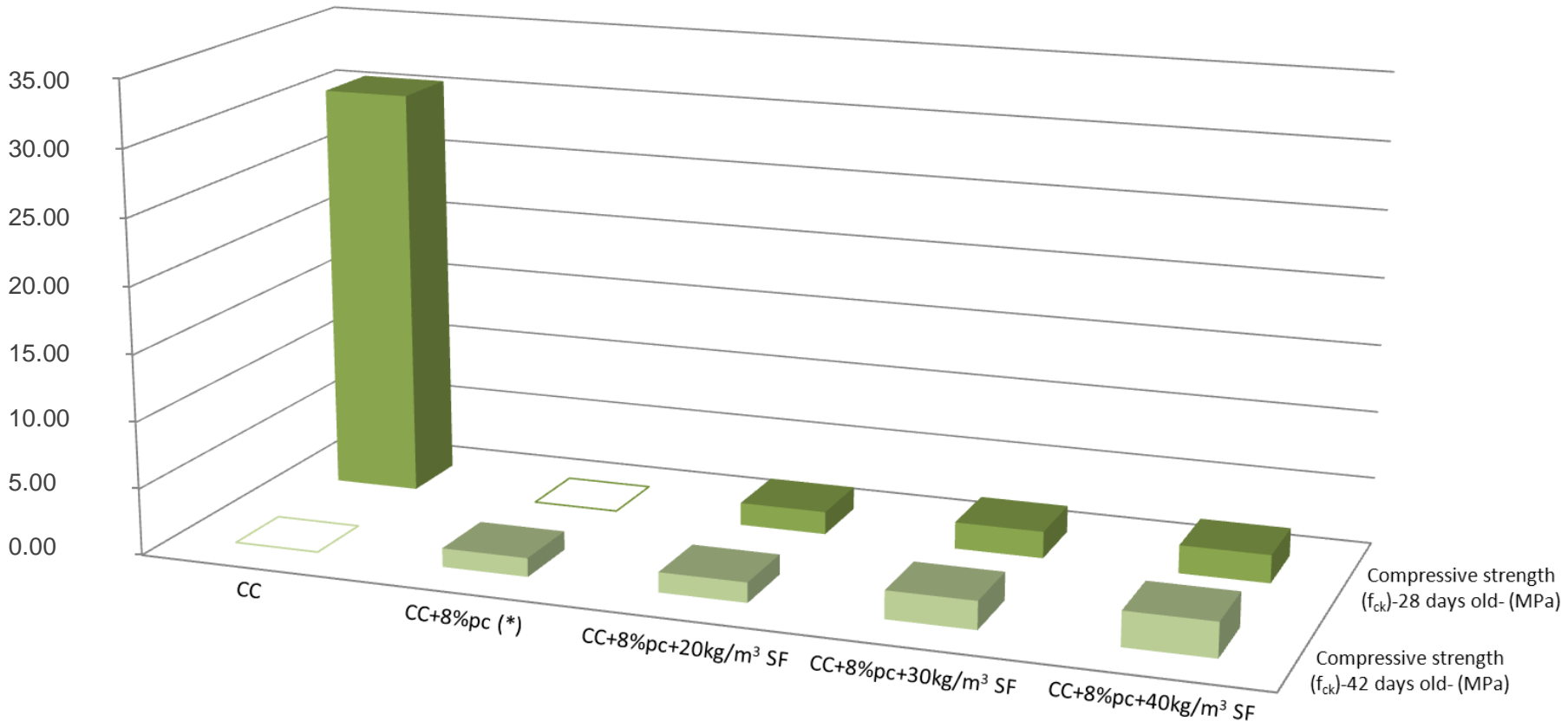

CC $\quad \mathrm{CC}+8 \% \mathrm{pc}^{(*)} \quad \mathrm{CC}+8 \% \mathrm{pc}+20 \mathrm{k} / \mathrm{m}^{3} \mathrm{SF} \quad \mathrm{CC}+8 \% \mathrm{pc}+30 \mathrm{k} / \mathrm{m}^{3} \mathrm{SF} \quad \mathrm{CC}+8 \% \mathrm{pc}+40 \mathrm{k} / \mathrm{m}^{3} \mathrm{SF}$

\begin{tabular}{|c|c|c|c|c|c|}
\hline Compressive strength $\left(\mathrm{f}_{\mathrm{ck}}\right)-28$ days old- $(\mathrm{MPa})$ & 30.70 & - & 1.70 & 2.00 & 2.10 \\
\hline Compressive strength ( $\left.f_{c k}\right)-42$ days old- (MPa) & - & 1.40 & 1.50 & 2.10 & 2.60 \\
\hline
\end{tabular}

Figure 7. Compressive strength results. 


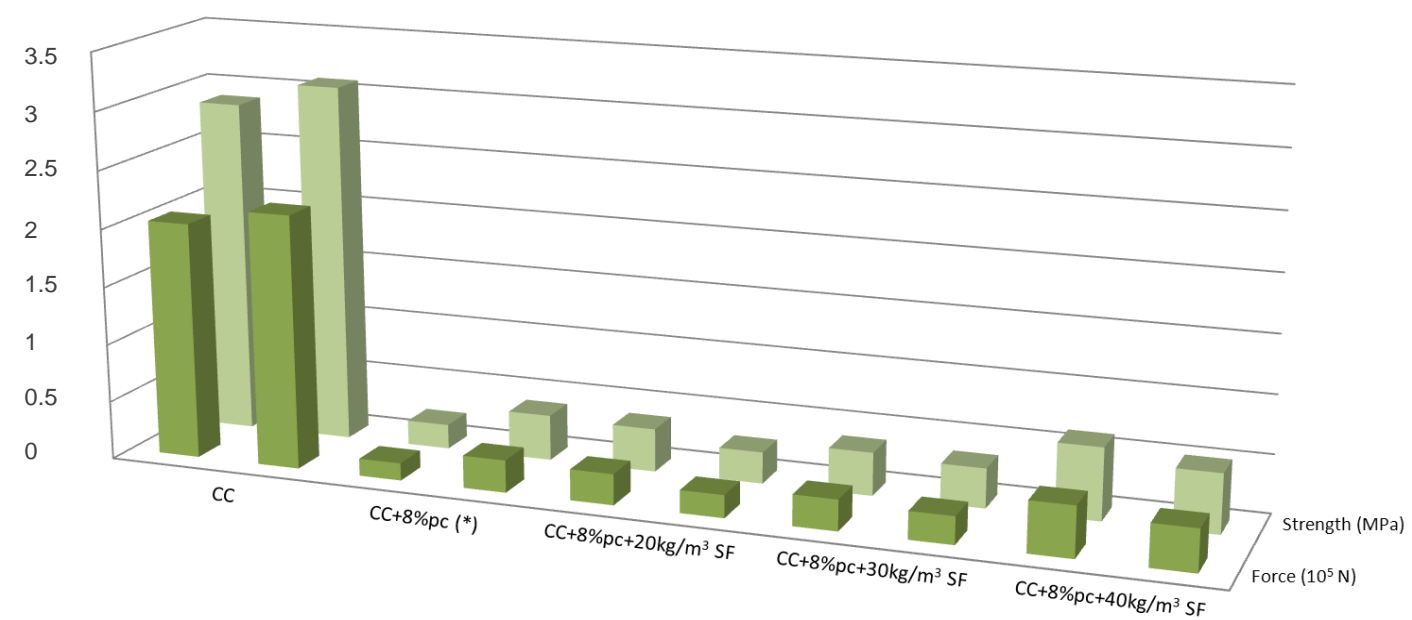

\begin{tabular}{|c|c|c|c|c|c|c|c|c|c|c|}
\hline \multirow[b]{2}{*}{ Force $\left(10^{5} \mathrm{~N}\right)$} & \multicolumn{2}{|c|}{ CC } & \multicolumn{2}{|c|}{$\mathrm{cC}+8 \% \mathrm{pc}\left({ }^{*}\right)$} & \multicolumn{3}{|c|}{$\mathrm{CC}+8 \% \mathrm{pc}+20 \mathrm{~kg} / \mathrm{m} 3 \mathrm{SF}$} & \multicolumn{2}{|c|}{$\mathrm{CC}+8 \% \mathrm{pc}+30 \mathrm{~kg} / \mathrm{m} 3 \mathrm{SF}$} & \multirow{2}{*}{ 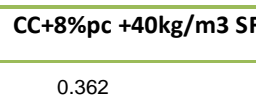 } \\
\hline & 2.038 & 2.188 & 0.149 & 0.278 & 0.265 & 0.195 & 0.266 & 0.238 & 0.435 & \\
\hline Strength (MPa) & 2.88 & 3.09 & 0.21 & 0.39 & 0.37 & 0.27 & 0.37 & 0.34 & 0.62 & 0.51 \\
\hline
\end{tabular}

Figure 8. Brazilian test results.

$$
f_{c t i}=\frac{2 P}{\pi L d}
$$

Where $L$ expresses the longitude of the specimen $(\mathrm{mm})$ and $d$ represents its diameter $(\mathrm{mm})$. The applied load $(P)$ is given in $\mathrm{kN}$ and the tensile strength $\left(f_{c t i}\right)$ in $\mathrm{MPa}$.

The Brazilian tests were performed at 28 days for control concrete and 42 days for the samples of cork powder concrete reinforced with steel fibers. The results (Figure 8) show that cork dust means a significant reduction in the concrete indirect tensile strength (cork powder concrete exhibits a 5 to 10 times lower indirect strength than control concrete) and that steel fibers only seem to improve significantly, approximately by $85 \%$, the indirect resistance behavior starting from an addition of $40 \mathrm{~kg} / \mathrm{m}^{3}$.

The values of tensile strength $\left(f_{c f}\right)$ were calculated according to Equation 3:

$$
f_{c f}=\frac{F \times l}{d_{1} \times d_{2}^{2}}
$$

Where $f_{c f}$ is the tensile strength (MPa), $F$ expresses maximum load $(\mathrm{N})$, I represents distance between the roller supports $(\mathrm{mm})$ and $d_{1}$ and $d_{2}$ are the lateral dimensions of the specimens.

The results (Figure 9) indicate that cork dust means a significant reduction in the concrete tensile strength (cork powder concrete exhibits a 4 to 6 times lower indirect strength than control concrete) and that the steel fibers only seem to improve significantly, approximately by $30 \%$, starting from an addition of $30 \mathrm{~kg} / \mathrm{m}^{3}$.

Recent literature reports have revealed a general consensus that incorporating cork in concrete reduces its mechanical properties (Silva et al., 2005; Branco et al., 2007; Simoes et al., 2007). Considering the results of this work, it is evident that the use of cork in the manufacturing of concrete means an almost total loss of concrete characteristic resistance, despite any improvement provided by the steel fibers. However, before dismissing the possible use of cork dust in concrete, further research would be advisable, especially in terms of cork's water absorption through the possibility of some kind of pretreatments or use of super plasticizers that could entail an improvement of the results presented in this paper.

\section{Conclusion}

Cork powder concrete, even containing steel fibers at rates up to $40 \mathrm{~kg} / \mathrm{m}^{3}$ is not suitable for structural use.

1) In general, concrete containing cork will have a dry consistency if no treatment is carried out.

2) To achieve a good mixing, it is necessary to mix slowly dry cork dust and aggregates and then add water and 


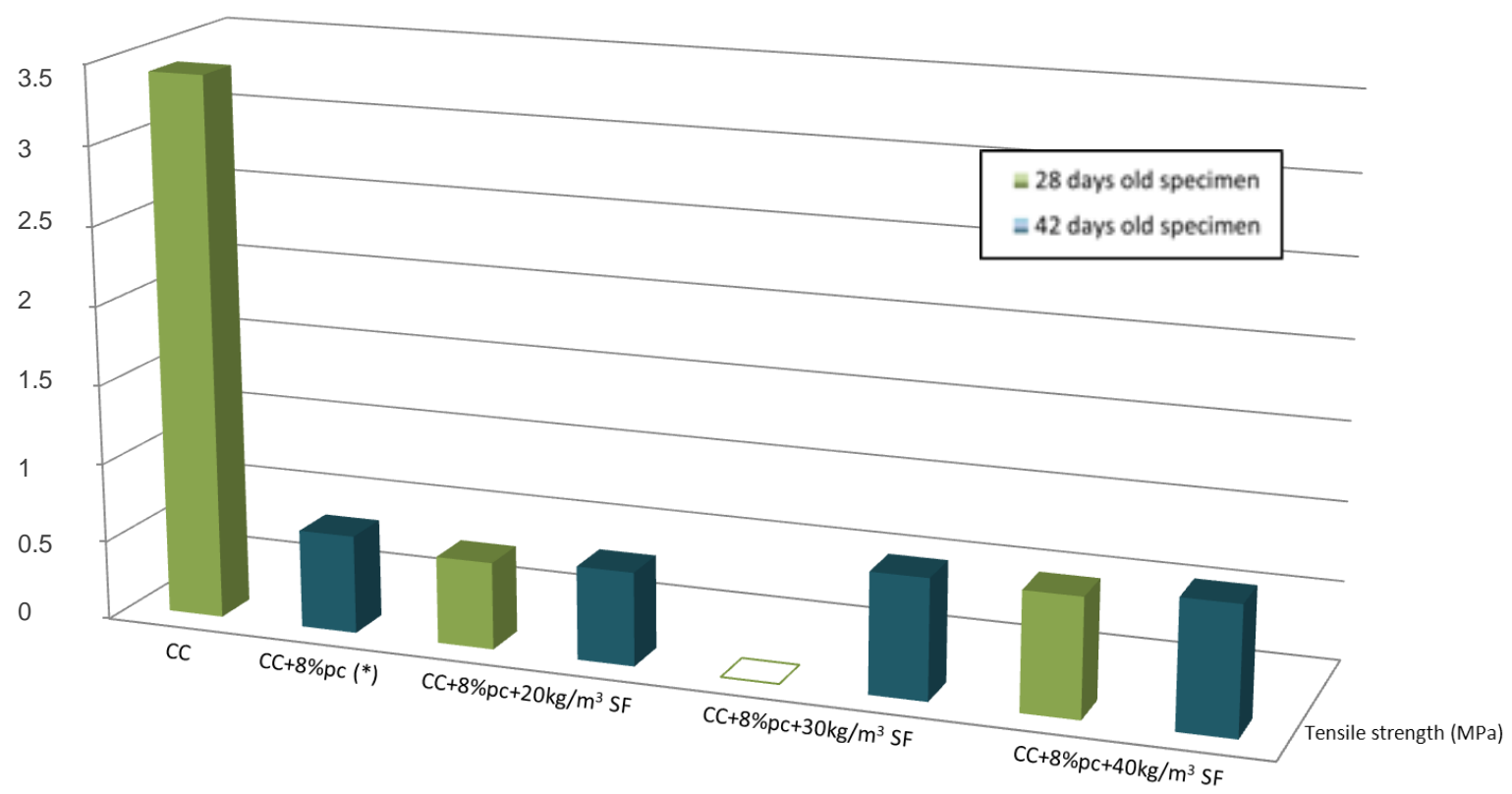

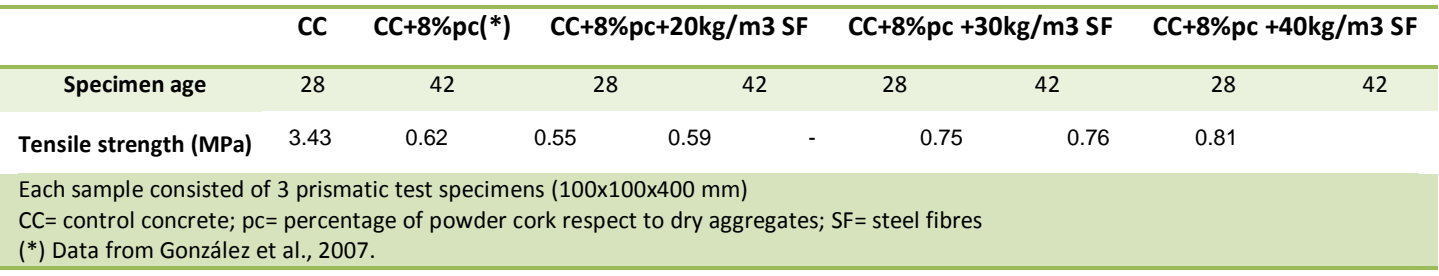

Figure 9. Tensile strength test results.

cement; and finally add the remaining water.

3) The final quantity of water should be increased (approximately 3.1 times higher than the calculated value) in order to compensate for the great cork's water absorption.

4) Due to the high amount of water required and if no temperature treatment is used, the setting and hardening are slowed. And as a result, it is necessary to wait at least 42 days to test the specimens, instead of 28 days as the Spanish Standard for Structural Concrete (EHE08) and other international standards stipulate.

5 ) The use of cork in concrete production means an almost total loss of concrete mechanical properties, despite the addition of steel fiber that improves its mechanical behavior.

6) Cork powder concrete reinforced with $40 \mathrm{~kg} / \mathrm{m}^{3}$ of steel fibers has provided better mechanical results. So, this concrete due to its use in non-structural applications, as well as for the aforementioned livestock pavement should be the basis for further and more specific testing according to the final use.

7) Finally, further research would be advisable, especially in terms of cork's water absorption through the possibility of some kind of pretreatments or use of superplasticizers.

\section{ACKNOWLEDGEMENTS}

This research was carried out with partly financial support from the "Junta de Castilla y León" (Spain). In addition, Julia García González would like to thank the Spanish Ministry for Science and Innovation for sponsoring her under the Research Training Program (FPI) grant number BES-2011-047159; and Desirée Rodríguez Robles would like to thank the Spanish Ministry for Education for sponsoring her under the University Training Program (FPU) grant number AP2010-0613.

\section{REFERENCES}

Arredondo F (1968). Dosificación de hormigones. Series manuales y normas del instituto de las Ciencias de la Construcción de Eduardo Torroja. Madrid. In: Spanish.

Aziz MA, Murphy CK, Ramaswamy SD (1979). Lightweight concrete using cork granules. Int. J. Lightweight. Concr. 1:29-33.

Branco F, Tadeu A, Reis M (2007). Can cork be used as a concrete aggregate? Int. J. Housing Sci. Appl. 31:1-12.

Carvalho APO (1996). Cork as a lightweight partition material. Economical and acoustical analyses. Proceedings of the CIB W89 Beijing International Conference held at Beijing, China.

de Belie N, Rombaut E (2003). Characterisation of Claw-floor contact pressures for standing cattle and the dependency on concrete 
roughness. Biosyst. Eng. 85:339-346.

di Maio AA, Traversa LP (2003). Evaluación de hormigones reciclados mediante ensayos no destructivos. Materiales de Construcción. 271272:37-46.

Gameiro CP, Cirne J (2007). Dynamic axial crushing of short to long circular aluminium tubes with agglomerate cork filler. J. Mech. Sci. 49:1029-1037.

Gameiro CP, Cirne J, Gérard G (2007). Experimental study of the quasi-static and dynamic behaviour of cork under compressive loading. J. Mater. Sci. 42:4316-4324.

Gameiro CP, Cirne J, Miranda V, Pinho-da-Cruz J, Teixeira-Dias F (2011). Dynamic behaviour of cork and cork-filled aluminium tubes: Numerical simulation and innovative applications. Holzforschung. 61:400-405.

Gil L (2009). Cork composites: A review. Materials 2:776-789.

González B, Llamas B, Juan A, Guerra MI (2007). Tests on concrete containing cork powder admixtures. Materiales de Construcción 286:83-90.

Guerra MI, Vivar I, Llamas B, Juan A, Morán J (2009). Eco-efficient concrets: The effects of using recycled ceramic material from sanitary instalations on the mechanical properties of the concrete. Waste Manage. 29(2):643-646.

Hernández-Olivares F, Bollati MR, del Rio M, Parga-Landa B (1999). Development of cork-gypsum composites for building applications. Constr. Build. Mater. 13:179-186.

Irle M, Karade S, Maher K (2004) Floating concrete! Light-weight concrete from granulated cork waste. Proceedings of ICECFOP1: 1st International Conference on Environmentally-Compatible Forest Products pp. 235-243.

Jiménez Montoya P, García Meseguer A, Morán Cabré F, Arroyo Portero JC (2010). Hormigón armado. 15 a ed. Barcelona. Gustavo Gili. 2010.

Juan Valdés A, Medina C, Guerra M I, Llamas B, Morán J, Tascón A (2010). Re-use of construction and demolition residues and industrial wastes from the elaboration of recycled eco-efficiente concretes. Spanish J. Agric. Res. 8:25-34.

Karade SR, Irle MA, Maher K (2001). Physico-chemical aspects of the use of cork in cementious composites. Proceedings of the ICWSF 2001- The Fifth International Conference on the Development of World Science, Wood Technology and Forestry held at Ljubljana, Slovenia, pp. 97-103.

Karade SR, Irle M, Maher K (2006). Influence of granule properties and concentration on cork-cement compatibility. Holz als Roh und Werkstoff. 64:281-286.

Mcllveen-Wright DR, Williams BC, McMullan JT, Evans RH, Gulyurtlu I (2000). Some energy and waste management options for cork processing plant. Environ. Waste Manage. 3:189-200.

Novoa PJRO, Ribeiro MCS, Ferreira AJM (2004). Mechanical behaviour of Cork-modified polymer concrete. Advanced Materials Forum II Book Series: Mater. Sci. Forum, 455-456:805-809.

Paulino M, Teixeira-Dias $F$ (2011). An energy absorption performance index for cellular materials - Development of a side-impact cork padding. Int. J. Crashworthines 16:135-153.

Pereira C, Jorge F, Neves AS, Coutinho JS (2004) Recycling of cork residues into cork-cement panels or light-weight concrete. Proceedings of ICECFOP1: 1st International Conference on Environmentally-Compatible Forest Products pp. 225-233.

Silva $R$ (2008). Melhoria da resposta sísmica de edifícios com recurso a paredes de CorBe. Master's thesis, University of Aveiro, Aveiro, Portugal.
Silva SP, Sabino MA, Fernandes EM, Correlo VM, Boesel LF, Reis RL (2005). Cork: Properties, capabilities, and applications. Int. Mater. Rev. 50:345-365.

Simoes N, Moreira A, Branco FG (2007). Effect of natural and expanded granulated cork on strength and thermal behaviour of concrete. Proceedings of the XXXV IAHS World Congress on Housing Science held at Melbourne, Australia.

Sousa JG. Bauer E, Sposto M (2003). Empleo de residuos en la construcción civil como áridos reciclados. Producción de bloques de hormigón. Materiales de Construcción 271-272:59-70.

Yagüe A, Valls S, Vázquez E, Kuchinow V (2003). Utilización de lodo seco de depuradora de aguas residuales como adición en adoquines de hormigón prefabricado Materiales de Construcción 267:31-41.

Zbigniew W, Kulczycka J, Fecko P, Kusnierov M (2005). Waste recycling. Wydawnictwo IGSMiE PAN held at Krakow, Poland.

\section{ANNEX A}

EN 1097-2 (1998). Tests for Mechanical and Physical Properties of Aggregates - Part 2: Methods for the Determination of Resistance to Fragmentation.

EN 1097-6:2000/A1 (2005). Tests for mechanical and physical properties of aggregates - Part 6: Determination of particle density and water absorption.

EN 12350-2 (1999). Testing Fresh Concrete. Part 2: Slump Test.

EN 12390-1:2000/AC (2004). Testing hardened concrete - Part 1: Shape, dimensions and other requirements for specimens and moulds.

EN 12390-2 (2000). Testing Hardened Concrete - Part 2: Making and Curing Specimens for Strength Tests.

EN 12390-3 (2001). Testing Hardened Concrete-Part 3: Compressive Strength of Test Specimens.

EN 12390-5:2000/AC (2004). Testing hardened concrete - Part 5: Flexural strength of test specimens.

EN 12390-6:2000/AC (2004). Testing hardened concrete - Part 6: Tensile splitting strength of test specimens.

UNE 83115 (1989). Aggregates for concrete. Determination of the coefficient of friability of the sands. 